Abstract P245 Table 1

\begin{tabular}{|c|c|c|c|c|c|c|}
\hline & \multicolumn{3}{|c|}{ East and West Yorkshire } & \multicolumn{3}{|c|}{ South Yorkshire } \\
\hline & $\begin{array}{l}\text { Mean Improvement } \\
\text { score (SD) }\end{array}$ & $\%$ Improvement & p value & $\begin{array}{l}\text { Mean Improvement } \\
\text { score (SD) }\end{array}$ & $\%$ improvement & p value \\
\hline Confidence in knowing the indications for bronchoscopy & $0.6(0.63)$ & 12.0 & 0.007 & $0.7(0.72)$ & 13.4 & 0.008 \\
\hline Confidence in knowing the contra-indications for bronchoscopy & $1.0(1.06)$ & 20.0 & 0.007 & $0.6(0.74)$ & 12.0 & 0.013 \\
\hline Confidence in accurately identifying all normal anatomy & $1.1(0.52)$ & 22.6 & $<0.001$ & $0.8(0.77)$ & 16.0 & 0.006 \\
\hline Confidence in knowing the complications for bronchoscopy & $0.7(0.72)$ & 13.4 & 0.008 & $0.5(0.64)$ & 9.4 & 0.020 \\
\hline Confidence in knowing the safe limits of conscious sedation & $1.2(1.08)$ & 24.0 & 0.003 & $0.9(1.03)$ & 18.6 & 0.008 \\
\hline Confidence in technical ability in handling the bronchoscope & $1.1(0.64)$ & 22.6 & 0.001 & $1.1(1.03)$ & 21.4 & 0.004 \\
\hline $\begin{array}{l}\text { Confidence in consenting the patient and quoting accurate } \\
\text { complication rates }\end{array}$ & - & - & - & $1.0(1.06)$ & 20.0 & 0.007 \\
\hline $\begin{array}{l}\text { Confidence with the correct dosage of lidocaine when anaesthetising } \\
\text { the airways }\end{array}$ & - & - & - & $1.3(1.23)$ & 26.6 & 0.003 \\
\hline $\begin{array}{l}\text { Confidence in using the appropriate sampling technique for each } \\
\text { suspected pathology }\end{array}$ & - & - & - & $1.5(0.99)$ & 29.4 & 0.002 \\
\hline
\end{tabular}

Authors 1 and 2 are first authors

\section{P246 RESPIRATORY PATIENT ACTIVITY, PHYSICAL EXERCISE IN NORMAL INDIVIDUALS, AND TELEHEALTH PREDICTION OF AIR POLLUTION}

doi:10.1136/thoraxjnl-2012-202678.307

M Morrison, KM Prentice, LJ Anderson, K Mcdowall, E Hopkins, L Macleod-Kennedy, JK Anderson, I Beverland, S Sneddon, K Anderson. Dept of Respiratory Medicine, University Hospital Cross house, Kilmarnock, Kilmarnock, Scotland

Background While air pollution is associated with morbidity and mortality in patients with respiratory and cardiac disease, there are also effects in normal individuals particularly if exercising on days when pollutants are high. The accepted advice on these days is to reduce exposure by restricting activity or remaining indoors. Consequently, in the European Union, high PM10 levels in 2005 caused $625 \mathrm{M}$ individual restricted activity days, encouraging national telehealth programmes, which incorporate this approach. Know and Respond, introduced in Scotland in February 2012, informs individuals by text, email, or landline message of the next day's air pollution prediction.

Study Five main focus groups were contacted-COPD patients registered with our LTOT service $(n=20$, age $55-73)$, in-patient respiratory patients ( $n=6$ COPD and $n=7$ asthmatics, age $24-75)$, regular recreational joggers from central Glasgow $(n=25$, age $24-30)$, competitive athletes ( $n=15$, age 21-26), and a group of occasional exercisers, who were predominately sedentary otherwise $(n=15$, age 25-30). Questions were asked about multimedia access, basic knowledge of air pollution and its' influence on daily activities.

Results Only 5 of the LTOT patients had internet access, and 7 had text receiving mobiles. All other subjects had internet access, and text phones. In the in-patient asthmatic group most were aware of the links between air pollution and health (6/7) and would change their exercise habits. In comparison only one COPD patient reported a link and consideration for air pollution when exercising. Some of the competitive athletes (13/15) and occasional exercisers (9/15) were aware of PM2.5 as a risk pollutant which might influence their choice of activity, but none of the joggers, who all ran regularly even during the high levels of air pollution in Glasgow during March 2012 when unseasonal weather patterns drew pollutant dusts from Europe across Scotland.

Conclusion We would reasonably contend that the aim of Know and Respond is justified given the known effects of air pollution however we acknowledge that awareness of the background relevance of air pollution is extremely variable. Know and Respond patient cards have been sent to general practise surgeries nationally to encourage patients to register with this free service.

\section{P247 IMPACT OF IMPLEMENTING COPD SELF MANAGEMENT PLANS \& RESCUE MEDICATIONS ACROSS 3 HOSPITALS}

doi:10.1136/thoraxjnl-2012-202678.308

${ }^{1} \mathrm{H}$ Khachi, ${ }^{2} \mathrm{M}$ Hodson, ${ }^{1} \mathrm{~V}$ Welsby, ${ }^{3} \mathrm{R}$ Hudson, ${ }^{4} \mathrm{CM}$ Roberts. ${ }^{1}$ Barts Health NHS Trust, London, UK; ${ }^{2}$ Homerton University Hospital NHS Foundation Trust, London, UK; ${ }^{3}$ UCL Partners, London, UK; ${ }^{4}$ BartsThe London School of Medicine and Dentistry, Queen Mary University of London, London, UK

Introduction COPD is the second leading cause of emergency admissions in the UK. National guidelines for managing COPD advise that patients at risk of having or those who have had an exacerbation of COPD should be given self-management advice that encourages them to respond promptly to their symptoms. As part of this, they should be given a course of oral antibiotics and corticosteroids to keep at

Abstract P247 Table 1

\begin{tabular}{lcccc}
\hline Hospital & \multicolumn{3}{c}{ COPD Readmission Rate \% } \\
\cline { 2 - 5 } & \multicolumn{2}{c}{$\begin{array}{l}\text { 30 day readmission for patients given and not given self } \\
\text { management plan \& rescue medication }\end{array}$} & $\begin{array}{l}\text { 90 day readmission for patients given and not given self } \\
\text { management plan \& rescue medication }\end{array}$ \\
\cline { 2 - 5 } & Not Given (\%) & Given Rescue Packs \& Plan (\%) & Not Given (\%) & Given Rescue Packs \& Plan (\%) \\
\hline $1(n=100)$ & 18.8 & 10.3 & 28.1 & 25.0 \\
$2(n=92)$ & 16.3 & 12.2 & 23.3 & 22.2 \\
$3(n=265)$ & 38.5 & 21.5 & 44.5 & 38.5 \\
Total & 29.7 & 17.2 & 36.6 & 32.3 \\
\hline
\end{tabular}

